\title{
RURAL ARCHITECTURE AND SUSTAINABILITY: LEARNING FROM THE PAST
}

\author{
Guliz Ozorhon *, Ilker Fatih Ozorhon \\ Department of Architecture, Faculty of Architecture and Design, Ozyegin University, Istanbul, \\ Turkey \\ *Corresponding author: guliz.ozorhon@ozyegin.edu.tr
}

Citation: Ozorhon, G., and Ozorhon, I.F. 2021. Rural Architecture And Sustainability: Learning From The Past. J. Asian Rur. Stud. 5(1): 30-47

\begin{abstract}
Traditional rural living environments have the potential to be instructive in numerous ways. Rural settlements, which are often created with a minimum of effort and have been around for thousands of years, can be a template for living environments of tomorrow. Starting off with that proposition, this paper goes on to emphasize the importance of examining the characteristics of traditional rural settlements in the context of sustainability. The article aims to analyze and thus improve our understanding of rural settlements, and in the process of doing so, it produces and reproduces knowledge within the field of sustainability. A model consisting of multiple layers was applied through the sampling of a particular rural-traditional settlement (Tarakl1), thereby shedding light on the relationship between the settlement and the parameters of environmental sustainability. In that model, three main methods of learning from traditional architecture were proposed: (1) Learning From Vernacular Architecture (LF-VA) through existing settlements; (2) Learning From Experience (LF-E) through those who have learned from vernacular approaches; and, (3) Learning from Research (LF-R). Through the use of that model, the data obtained constitutes a holistic pool of information. The basic facts articulated in this pool are models, concepts and theories, and the prominent concepts include documentation, conservation, adaptation and innovation. As a result of the analysis based on the model, the relationship of the physical characteristics of the rural-traditional settlement exemplified in the article with the environmental sustainability parameters has been illustrated systematically. In the literature, the products of rural architecture generally exist with identification and documentation studies. In this article, the relationship between rural architecture and sustainability is discussed in the context of learning from the past and it is shown through an existing settlement.
\end{abstract}

Keywords: Rural Architecture; Sustainability; Rural Settlements; Vernacular Architecture

\section{Introduction}

Issues surrounding sustainability have become crucial topics of debate in the 20th century. As such, it has been high on the agenda in almost every field, ranging from politics to engineering and from the economy to food and water. As a reflection of this state of affairs, international meetings are held on the issue, numerous reports have been published, research is being conducted, countless dissertations have been written, and plans of action have been drafted and implemented. Statesmen, scientists, artists and 
journalists alike have discussed future-oriented strategies as they try to come up with better ways of attending to the needs of humanity. Across a wide variety of fields, similar questions have arisen, such as: What should we do for a better future? How are we responsible for the ecosystem as scholars, engineers, sociologists, teachers, mothers and humans, or simply as sentient, living beings?

The discipline of architecture has also addressed the issue of responsibility. Every new structure that is built introduces new interventions into nature, so it can safely be argued that the act of designing and creating buildings basically involves actions that run counter to the order of the natural world. However, how such interventions are carried out - in other words, the attitude underpinning the products of architectureaffects the continuity of this relationship.

The repertoire of rural architecture contains an abundance of abstract forms and types of creative expression that have obvious connections to the land, climate, and economy, as well as technologies (Sabatino, 2010) . By looking at such environments, we can clearly see the harmony that informs them. They reflect an approach that is embedded in nature, working in parallel with local topographies in addition to air and water currents instead of fighting against natural forces. However, that should not be taken to be a conscious choice but rather as a means of survival that has developed over the course of time, and there is much we can learn from these settlements. It should be noted here that this perspective is not entirely new, as past researchers also examined rural environments. For example, a review of articles about the issue in the Scopus database indicates that 2,713 studies focusing on rural settlements have been carried out since 1924. That body of research is quite diverse in terms of fields and scope, including environmental studies, urban planning, archeology, architecture, ecology, geography, history, water resources, and so on, and $13.57 \%$ of those studies concern rural settlements in relation to architecture.

Some studies on rural/local/traditional settlements are in the form of documentaries, which are a useful means of both transferring the concrete products of living culture to future generations and providing data for researchers who can thus expand their studies in various contexts. On the one hand, they provide support for conservation and preservation efforts, and on the other hand they offer systematic structural information about the research environment and prepare the ground for the generation of new sets of data from particular points of view.

Especially in recent years, the amount of research that focuses on trying to learn from rural, local and traditional settlements has increased significantly. Indeed, rural 
settlements provide researchers with open and living sources of information in a wide variety of contexts.

Likewise, this article aims to analyze and thus improve our understanding of rural settlements, and in the process of doing so, it produces and reproduces knowledge within the field of sustainability. Examining rural architecture is not only useful but also necessary if we want to understand existing causal relationships that purely stylistic analyses of architecture have led us to forget (Sabatino, 2010). Egyptian architect Hasan Fathy has been a leading proponent of this perspective in the architectural milieu. Through the New Gourna project, Fathy, in addition to examining the construction economy, climatic comfort and traditional culture-based tectonic-aesthetic forms of expression made possible with traditional materials and techniques, started to reflect on the identities, needs, and relational expressions of family groups that make up village societies, even taking into account how households exist within and through space (Yücel, 2000). Exploring rural architecture is crucial for choosing conscious approaches to culture, understanding the larger picture, seeking out continuities in culture, and bridging the past and the future in opposition to an approach to architecture that has spread all around the world, ultimately becoming so commercialized that architecture has been reduced to being an object of consumption.

\section{Methodology}

This study focuses on learning from the past in architecture. To that end, the authors employed a model ("Learning From the Past," henceforth LFP) that they developed in their previous studies (Authors, 2019). In that model, three main methods of learning from traditional architecture (Fig.1) were proposed: (1) Learning From Vernacular Architecture (LF-VA) through existing settlements; (2) Learning From Experience (LFE) through those who have learned from vernacular approaches; and, (3) Learning from Research (LF-R). Through the use of that model, the data obtained constitutes a holistic pool of information. The basic facts articulated in this pool are models, concepts and theories, and the prominent concepts include documentation, conservation, adaptation and innovation. However, a critical question arises at this point: How can the data that comprises the information pool can be transferred to the future and from there to the architectural environment? Some key concepts in this regard are identity, continuity and sustainability. 


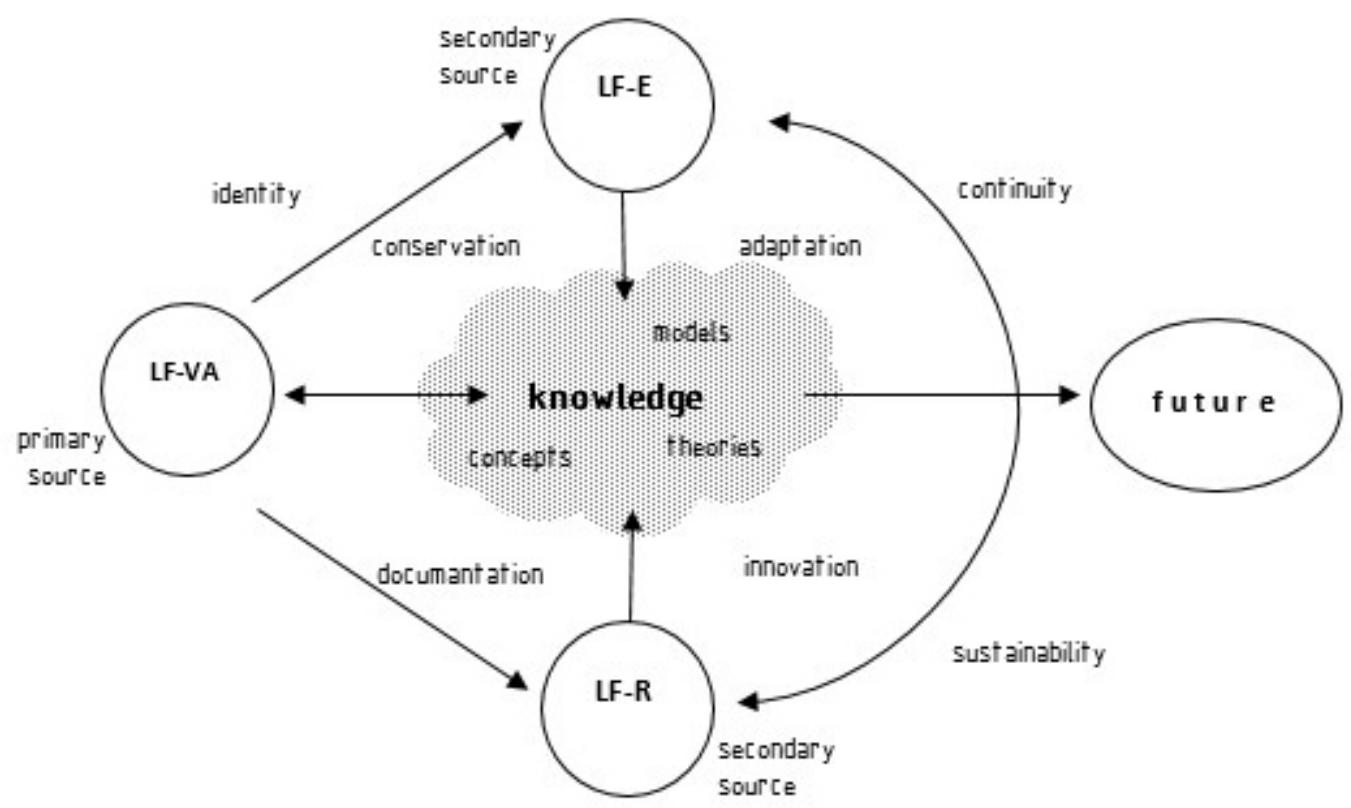

Figure 1. The guidelines and components of learning about local architecture and the relationships between those components (Authors, 2019)

This article focuses on the LFP model by examining rural architecture and the potential for learning from rural architecture within the context of sustainability. Such an approach, as shown in Fig. 2, requires a firm grasp of rural architecture and the role that sustainability plays therein.

Although the issue of sustainability encompasses a large field with many sub-topics, this study deals in particular with its environmental dimensions. Following a literature survey, the paper explores the issue of sustainability in rural architecture. As a case study, the settlement of Tarakl1 is examined in depth, making it possible to raise to the surface further details pertinent to the study at hand. With that aim in mind, two aspects of LFP (LF-VA, learning from settlements) and LF-R (learning from researchers) were used together, along with the literature review (LF-R), on-site observations, field work and analyses. Lastly, in terms of sustainability, the authors sought to learn from the example of Taraklı and thus transfer knowledge from the past to the future. 


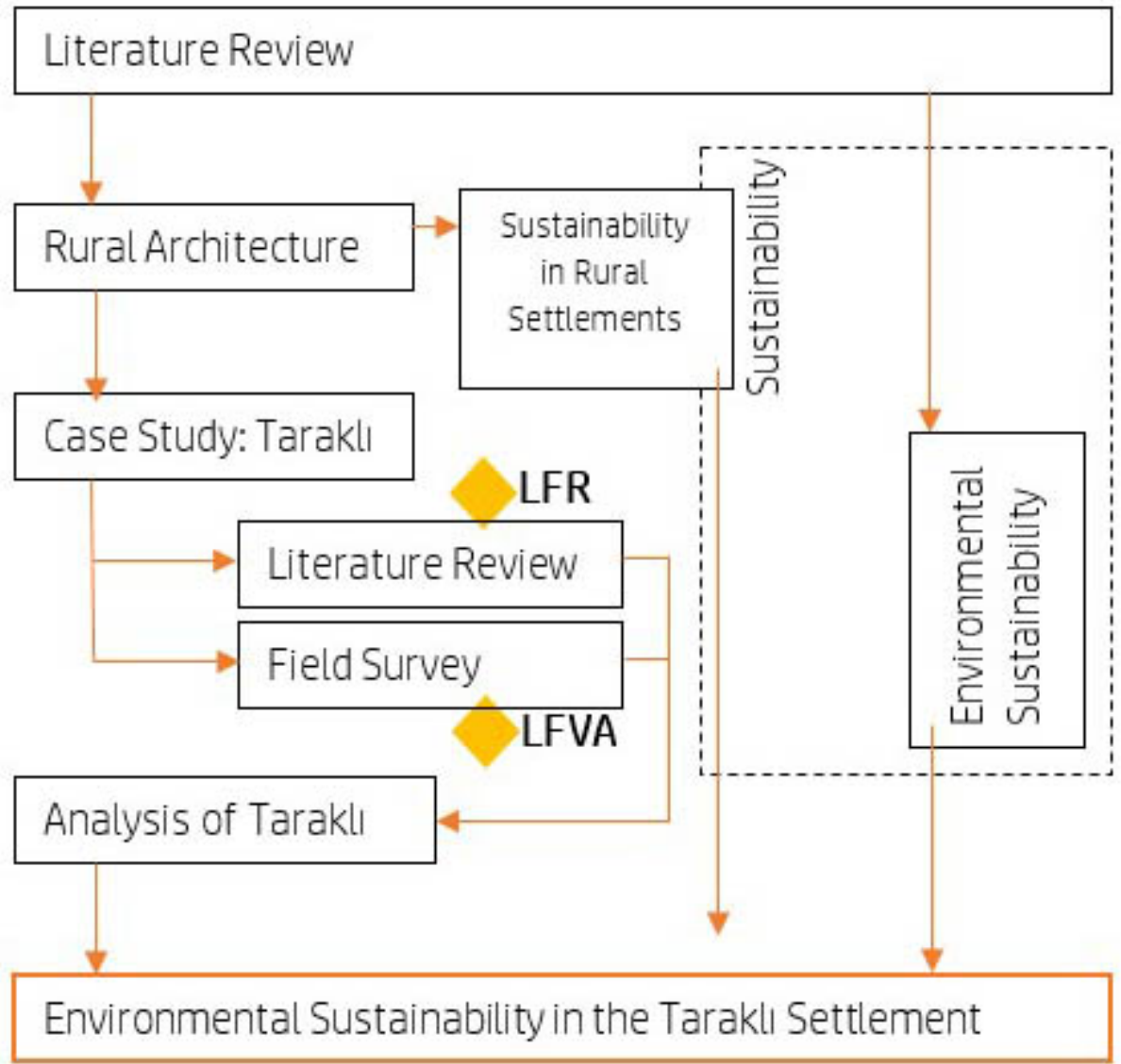

Figure 2. Strategy of the Study

While one of the aims of this study is to reveal the architectural identity of Taraklı by means of a literature survey and on-site analyses, the main goal is to investigate how instructive the characteristics of Taraklı settlement can be in terms of sustainability.

\section{Rural Architecture and Sustainability}

Since one of the goals of sustainability is "to meet the needs of the present without compromising the ability of future generations to meet their own needs" (Burtland Report, 1987), rural settlements are surely ideal means of seeing that notion at work. Rural buildings and settlements are unique examples of the interaction between people and nature. Here, it will be useful to note that rural architecture refers to buildings constructed by everyday craftsmen, not professional architects who are often committed to a design methodology. In that way, rural building designs often evolve over time and differ from structure to structure, and for that reason, they tend to effectively steer clear 
of design stagnation. Such buildings often exist in harmony with their natural environs and have little to no negative impacts on the environment.

But what exactly is rural architecture? That question, in fact, embodies a certain contradiction. When dealing with rural settlements, it would perhaps be more accurate to speak of "architecture without architects" (Rudofsky, 1964). According to Sözen (2012), rural architecture is best described as "the architecture of the people made by the people." It is the architecture of certain periods and regions, and it is often inclusive of housing. Natural features such as climate, geographical elements, soil, water, and local materials, not to mention culture, are the main factors involved in the formation and development of rural architecture (Sözen, 2012). One prominent aspect of rural structures is a natural characteristic that can be likened to how animals change through natural processes of evolution. As they are not built following the tenets of any given artificial style, buildings represent a natural response to the traditional requirements of pre-industrial society and the limitations imposed by space and climate. As a result of the evolution of the craft of construction, the advanced methods employed have resulted in beautiful, simple and original forms of production (Aran, 2000).

Rural settlements are environments that reflect the physical conditions of regions and the lifestyles predominant at any given time, and thus they are a form of public architecture. Rural settlements in many regions today that have managed to maintain their sense of locality often combine richness of form and rational solutions compatible with regional materials and local conditions. When local solutions develop in line with regional conditions, rural settlements acquire an original identity that arises in relation to the natural environment (Eminağaoğlu, 2007). Structures that merge architecture and rural culture may bear traces of the past with their original identities through a reflection of culture, social relations, the habits of ordinary people in their daily lives, ordinary tastes, beliefs, and the priorities of landlords and craftsmen.

"Rural craftsmen keep in mind their methods. They transfer knowledge about materials based on sensory data and the thought patterns and approaches to building passed down to them from one generation to the other in an effective verbal-based apprentice relationship, and that continues through a shared culture with traditions and customs. The methods of rural craftsmen are based on designs that are not written down or drawn. As a result, traditional knowledge is not recorded through written documents or drawings" (Aran, 2000). In that sense, these structures, which represent a merging of architecture with rural culture, carry with them traces of the past. 
Spontaneous practices that arise through local characteristics are original and therefore need to be documented. Carrying out evaluations of such buildings together with their geographical and cultural contexts is important in terms of carrying on cultural richness and perpetuating through memory those processes that are involved in housing production (Şenol \&Akan, 2011). Traditional settlement patterns, which reflect the original culture that gave rise to them, are generally accepted as being aspects of cultural heritage as long as they can transfer their original character and reasons for existence from generation to generation (Oliver, 1998).

Traditional settlement patterns represent the art of relations arising from the dynamic interaction of built environments that come into being through a certain pattern of cultural accumulation. Our understanding of conservation must adopt a planning and design approach that can connect the past to the present, maintain the continuity of spaces and revive a sense of belonging to ensure the continuity of this art of relations (Koca, 2015).

\section{Case Study: Taraklı, An Anatolian Settlement}

The Taraklı settlement is located in the southeast of the Marmara Region, $270 \mathrm{~km}$ from Ankara, $200 \mathrm{~km}$ from Istanbul and $65 \mathrm{~km}$ from Sakarya (Fig. 3). It is located 34 $\mathrm{km}$ from the Göynük district of Bolu province in the east and $30 \mathrm{~km}$ from the Gölpazarı district of Bilecik province in the south.

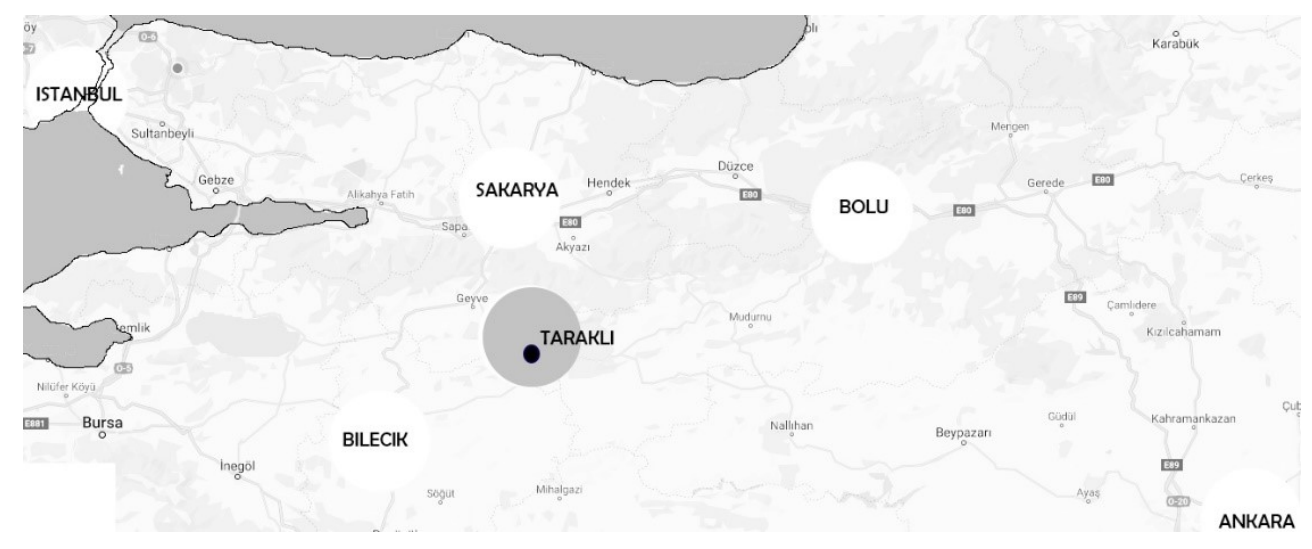

Figure 3. Map indicating the geographical location of Taraklı

Taraklı has been home to various civilizations since time immemorial (including the Hittites, Phrygians, Persians, Hellenes, Bithynians, Romans, Anatolian Seljuks, Byzantines and Ottomans) (Özyer, 2008). It is one of the few Anatolian cities that has survived to the present day with its layout and street plan intact. 
The fact that Taraklı's economy is based on agriculture, animal husbandry and the production of silk from silkworms, which played an important economic role in the city in the past, has had a direct impact on the shaping of traditional architecture. The physical structure of the settlement developed spontaneously due to its geographic and topographic features; since Taraklı is located on sloping terrain, the buildings are constructed in parallel to the slope, and they were built in such a way that they do not block each other's access to sunlight or breezes.

Tarakl1 was declared a protected area in 1992 and it was accepted as a member of the Cittaslow International after a meeting was held in Poland on June 26, 2012 at the behest of the local municipality. Once the town acquired membership in the association, more importance was placed on preservation work such as natural and environmental protection, preserving the city's historical silhouette and raising awareness among the people about the history of the area. Restoration work was facilitated in Taraklı by the passage of a Regulation Concerning Assistance for the Restoration of Immovable Cultural Properties, which came into force in 2005, and a restoration workshop was held in 2006 (Degirmenci \& Sarıbıyık, 2015). In this process, some buildings in Taraklı that were considered landmarks were restored and work is still ongoing. Changes were also introduced in terms of how the buildings are now used. While some of them were slotted for use as accommodations and thus contributed to the sustainability of tourism, others have been used to display the characteristics of the region in terms of its cultural buildings (Aktürk et al., 2019).

A review of the academic research that has been carried out about Tarakli reveals that studies have focused on issues like identification/documentation resulting in conservation and restoration proposals (Demir, 1988; Seymen, 2008; Özkan, 2008; Özyer, 2008; Benli \& Kan, 2013; Başoğlu, 2017; Turgay\& Erkuş Buyruk, 2017), the sustainability of the city's historical fabric (Kan, 2009), the concepts of sustainability and ecology in the settlement (Erek, 2015), and the sustainability of tourism (Aktürk et al., 2019). This article examines the physical properties of Taraklı with a particular focus on sustainability.

\subsection{General Characteristics of the Settlement}

The climates of the Black Sea, Mediterranean and Central Anatolia all have an impact on Taraklı. Summers are hot and dry, while winters are rainy and cold. Annual rainfall is approximately $630 \mathrm{~mm}$ and the average annual temperature is $14-15$ degrees. $20 \%$ of Taraklı's land is used for agriculture, $60 \%$ of it is forest and heathland, $10 \%$ of 
it is meadows and pastures, and $10 \%$ of it is non-agricultural (Seymen, 2008). The two most important features that have shaped the district of Tarakl1, which is located on slopes overlooking a narrow plain, are Ankara Street, which passes through the middle of the district and connects it to the main thoroughfare, and Göynük Creek. Taraklı is surrounded by lush, forested mountains and hills. Because of its geographic location and thermal springs, Taraklı is also well-known as a destination for health retreats. In many ways, it is a typical Ottoman settlement; in addition to houses, there are mosques, schools, Turkish baths, fountains, inns, municipal buildings and shops. The streets, by organically following the topography, are rather narrow and traditionally they are cobblestone. Still, the city lanes are wide enough for cars to drive on, although some of them are too steep for vehicular traffic.

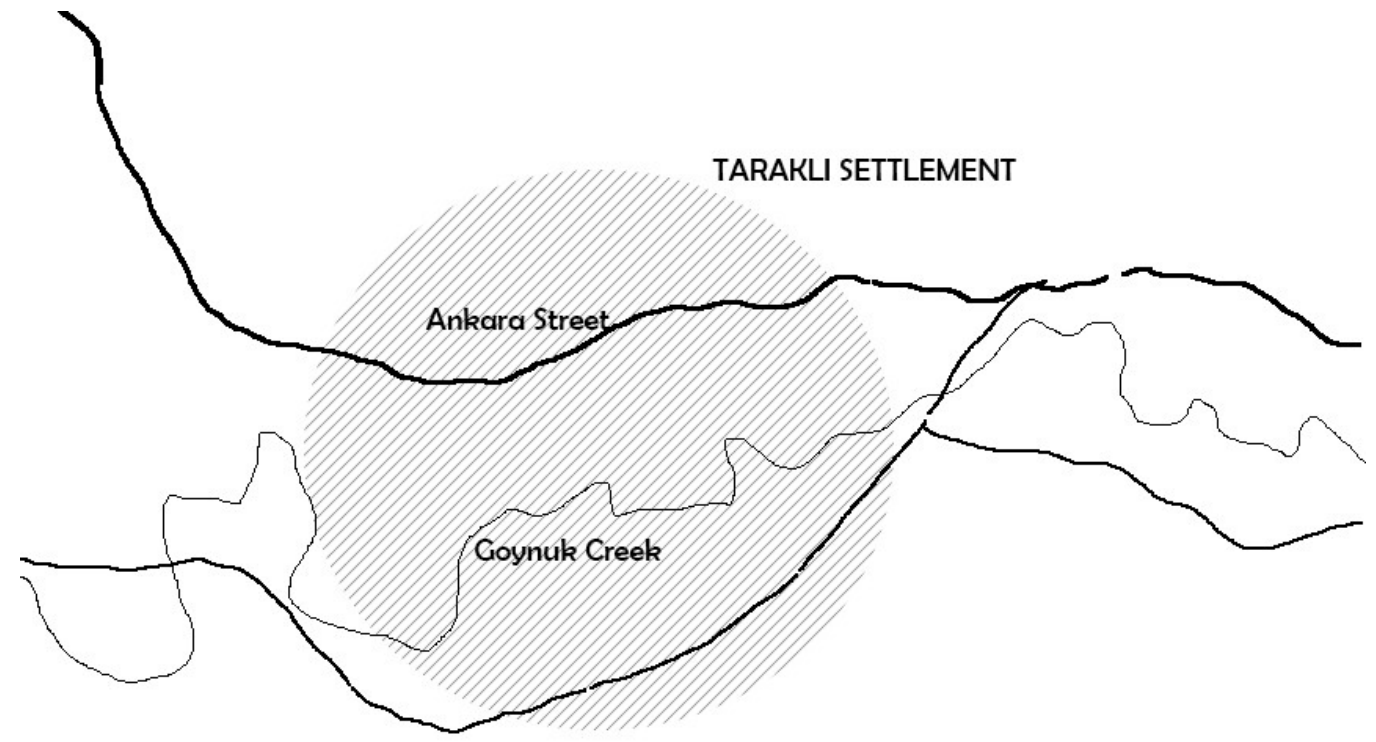

Figure 4. Major features of Taraklı settlement

\subsection{Housing}

Although the majority of traditional houses in Taraklı are two-storey buildings, here and there single- and three-storey homes can be seen as well. Family structures, the climate, the topography and local culture have played a major role in shaping the evolution of the settlement and the design of buildings. In general, traditional houses are located along the streets and the entrances of the houses are situated on the buildings' facades. Houses traditionally have courtyards behind them and these are surrounded by mudbrick, stone or wooden walls called daraba. These courtyards are used not only for 
daily activities but also for keeping goods, storing hay, baking and keeping poultry (Davulcu, 2009). The ground, which serves as the foundation for the upper floors, follows the contours of the topography. When it is paved with stone, it is called a taşlık, but otherwise it is referred to as hayat. The ground floor of the house is covered in slate, and there is usually a spacious area and a kitchen in a corner. Kitchens facing the courtyard or street façade have stoves, sinks and shelves, and these spaces are illuminated with small windows. Some houses have wells (Kan, 2009). Research conducted by Seymen(2008) indicated that 38 out of 417 original buildings in the settlement were single-storey, 331 were 2 -storey and 58 were 3 -storey structures. The same study emphasized that today most of the buildings continue to be used in line with their traditional characteristic functions.
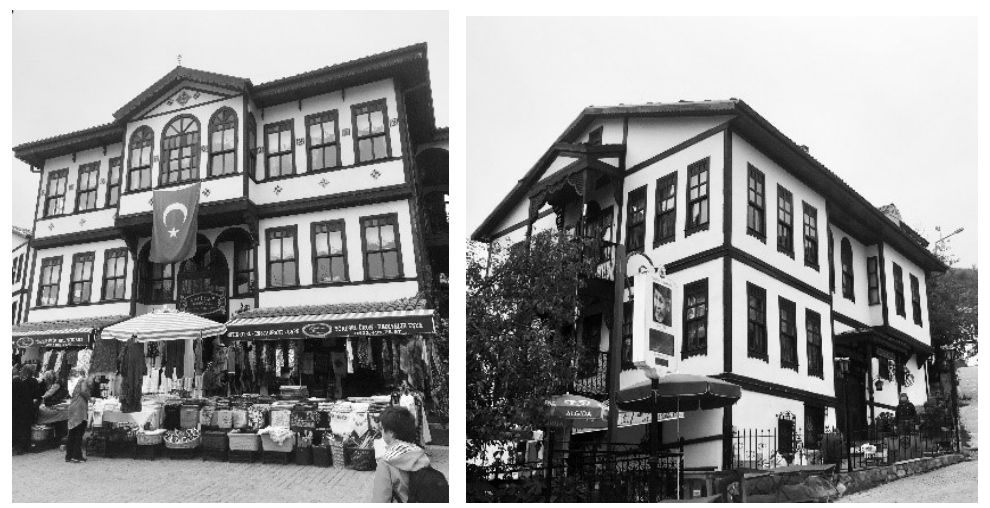

Figure 5. Examples of traditional Taraklı houses

The houses are situated in a side-by-side fashion along the street or separately within a garden. The entrances of the houses are generally located along the central axis of the façade. Rectangular or triangular oriels, or bay windows, supported by wooden buttresses not only visually enrich the structures, but also provide additional interior space and allow for more sunlight. On the ground floors of some buildings, there are stables and so forth, and on the first floor of the houses (the living space), there is a sitting/gathering area known as a sofa in Turkish, a kitchen and other rooms that open onto the interior space. 

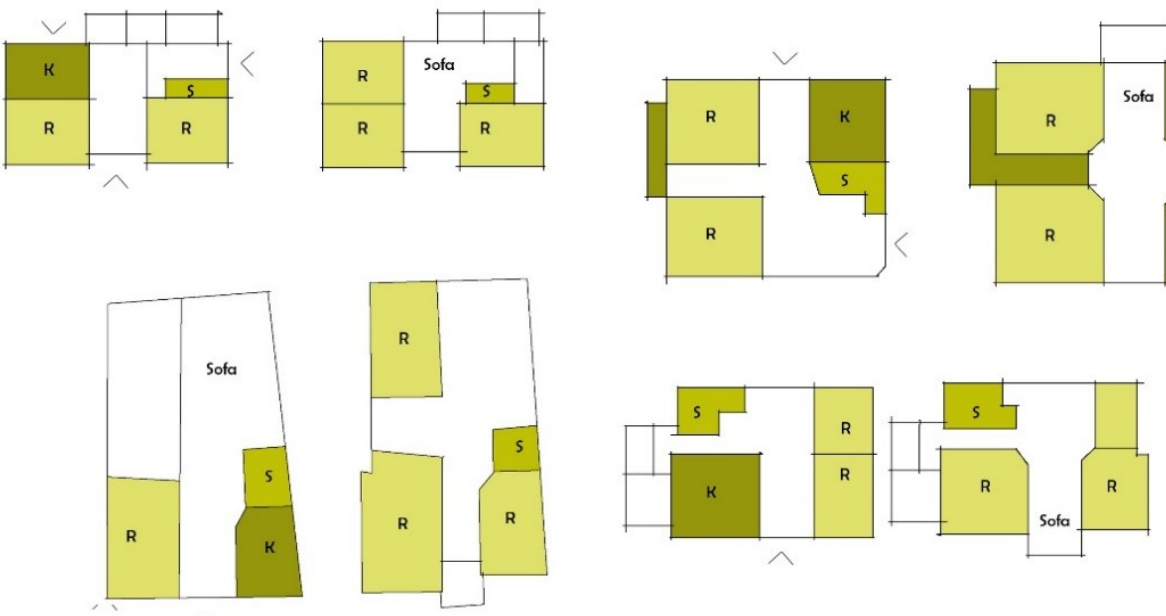

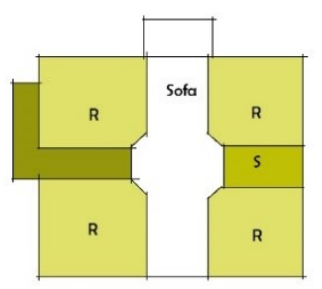

Figure 6. Some floor schemes of Taraklı houses (R: Room, K: Kitchen, S: Stairs)

Just as the houses open onto the street, all of the spaces in the house open onto the sofa. The sofa is a passageway leading to the other rooms, but it is also where people gather and ceremonies are held. The sofas are wider here than in classical Turkish houses, since making silk from silkworms is common in the villages, including the town center in Tarakl1, so space is needed for related production activities. As in almost all examples of traditional Turkish architecture, the most important elements of houses are the rooms. These rooms are all designed to accommodate a husband and a wife. Here one can sit, lie down, cook, eat and even wash up. One of the rooms, however, is different from the others; these rooms are referred to as the baş odas1, and they are reserved for guests. Normally located near the stairs, they tend to have the most beautiful views, and generally both walls of these rooms have windows. If the house has a bow window, this is where it is located.

\subsection{Building Façades and Structural Systems}

Traditional buildings in Taraklı are built with mudbricks or brick-filled wooden frames. Since the region is covered in forests, the easiest building material to obtain is wood. Wooden vertical supports rest on stone foundations, and a wooden framework is used for the upper floors, which are also covered in wood. The main reason why Tarakl1, which is located in a first-degree earthquake zone, has survived numerous earthquakes with only minor damage is because the majority of the buildings are built with traditional wooden framing systems. A characteristic element of this system is the 
use of buttresses to support floor extensions that protrude beyond the walls of the houses. Wooden framing blocks filled with mudbrick are used for the interior and exterior surfaces. Plastering is used, either with mud plaster and straw directly applied and completely dried with flax and thin plaster, or bagdadi plaster is applied over thin wooden planks slathered with mud plaster (Seymen, 2008). The roofs are gabled and covered with terracotta tiles.
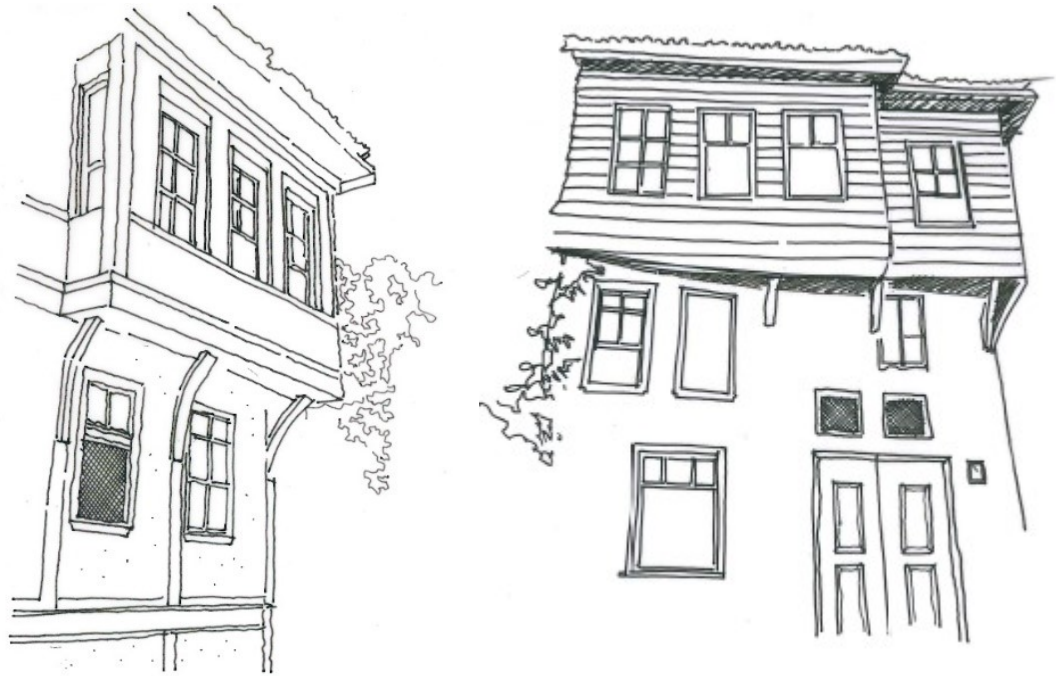

Figure 7. Examples of building façades in Taraklı

\subsection{General Evaluation}

In this section, information obtained about Taraklı architecture- from academic studies as well as on-site observations and evaluations - is brought together and a table identifies key characteristics. Table 1 indicates the architectural structure of buildings in the Taraklı settlement and identifies them under three main headings:

(1) The characteristics of the settlement

(2) The characteristics of traditional houses

(3) Building façades

Thus, the overall layouts are presented with their particular parameters in terms of layers. 
Table 1. Analysis of the Tarakl1 Settlement

\begin{tabular}{|c|c|c|c|c|}
\hline \multirow{6}{*}{ ¿্ঠ } & \multirow{6}{*}{ 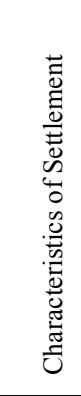 } & \multicolumn{2}{|c|}{ Relationship with the climate } & Climate-compatible material selection, spatial organization. \\
\hline & & \multicolumn{2}{|c|}{$\begin{array}{l}\text { Relationship with the } \\
\text { topography }\end{array}$} & Settlement-compatible with the hilly terrain and a minimum of leveling. \\
\hline & & \multicolumn{2}{|c|}{ Orientation } & Landscape orientation, southward orientation. \\
\hline & & \multicolumn{2}{|c|}{ Relationship with sunlight } & $\begin{array}{l}\text { Orientation to the south, orientation of areas where daily life can take } \\
\text { advantage of sunlight. }\end{array}$ \\
\hline & & \multicolumn{2}{|l|}{ Streets } & Narrow, as a result of the topography. \\
\hline & & \multicolumn{2}{|c|}{$\begin{array}{l}\text { Relationship between streets } \\
\text { and buildings }\end{array}$} & Street houses (direct), street-garden houses (indirect). \\
\hline \multirow{8}{*}{ 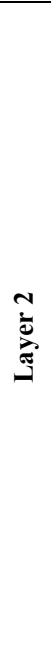 } & \multirow{8}{*}{ 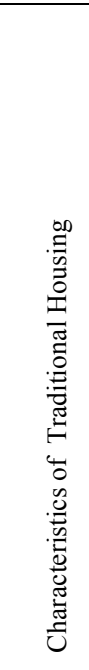 } & \multirow{2}{*}{\multicolumn{2}{|c|}{ Original/Important Spaces }} & $\begin{array}{l}\text { Rooms: Spaces of suitable size and equipped with furnishings for activities } \\
\text { like sleeping, resting, eating, etc. }\end{array}$ \\
\hline & & & & $\begin{array}{l}\text { Sofa: Focal point of houses. } \\
\text { Indoor humidity is optimized by effective natural air circulation in the } \\
\text { summer months with window openings on various façades of the sofa. }\end{array}$ \\
\hline & & \multicolumn{3}{|c|}{ Spatial organization } \\
\hline & & \multirow{5}{*}{$\begin{array}{l}\text { Design of } \\
\text { houses }\end{array}$} & Height & $\begin{array}{l}\text { In the houses, the intermediate floors have low ceilings and the upper floors } \\
\text { have high ceilings; mezzanine floors are called "winter floors" and upper } \\
\text { floors are referred to as "summer floors." }\end{array}$ \\
\hline & & & Eaves & $\begin{array}{l}\text { Eaves are used both as protection against rainfall and to prevent the direct } \\
\text { penetration of sunlight into the houses during the hot summers. }\end{array}$ \\
\hline & & & Bay Windows & $\begin{array}{l}\text { Bay windows on the upper floors allow the building to be opened up to the } \\
\text { landscape, garden and street as much as possible, and they take advantage of } \\
\text { daylight. }\end{array}$ \\
\hline & & & Structure & Adobe or brick-filled wood framing system. \\
\hline & & & Form & 2- (mostly) or 3-storey compact framed structure. \\
\hline \multirow{4}{*}{ 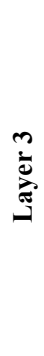 } & \multirow{4}{*}{ 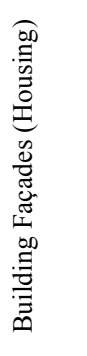 } & \multirow{2}{*}{ Walls } & Form & 2- (mostly) or 3-storey compact framed structure. \\
\hline & & & Materials & Wood, stone, adobe, linen, straw. \\
\hline & & \multirow[t]{2}{*}{ Windows } & Form & $\begin{array}{l}\text { Large, abundant upper-floor windows maximize natural ventilation and } \\
\text { natural lighting while increasing visibility within the space. } \\
\text { On some exterior doors, there are latticed openings that provide natural } \\
\text { lighting and ventilation for the interior (i.e. allowing hot air in the interior to } \\
\text { be vented outside). }\end{array}$ \\
\hline & & & Materials & Wood. \\
\hline
\end{tabular}

\section{Lessons From Taraklı in The Context of Sustainability}

The spaces created by the buildings in Taraklı are original in terms of their design and they are well-suited to the environment, meaning that they are healthy spaces in which to live because they are closely connected with the physical characteristics of the area. The relationship between the characteristics of the settlement and the parameters of environmental sustainability are presented below in Table 2, which illustrates how sustainability neatly corresponds with the local conditions. As indicated in the table, 
Tarakl1 fulfills the requirements of environmental sustainability parameters.

For example, the establishment of the settlement in harmony with the topography (rather than "in spite of" it) facilitated the construction of buildings that have a minimal impact on the land and soil. The orientation of buildings to the south provides maximum benefits in terms of daylight and solar energy, so illumination and warming are largely provided by natural means. In particular, living areas are located in the south and service spaces are situated in the north. The houses are constructed in a compact manner, which prevents the over-consumption of materials and energy. Also, buildings are made with natural/local materials (such as wood and stone) which can be obtained nearby (for structures, façades and interiors), thus creating healthy living spaces. The roofs of the buildings are sloped to ensure that water runs off during the rainy season, and eaves around the buildings protect the walls against moisture.

Table 2. Environmental Sustainability in the Tarakl1 Settlement

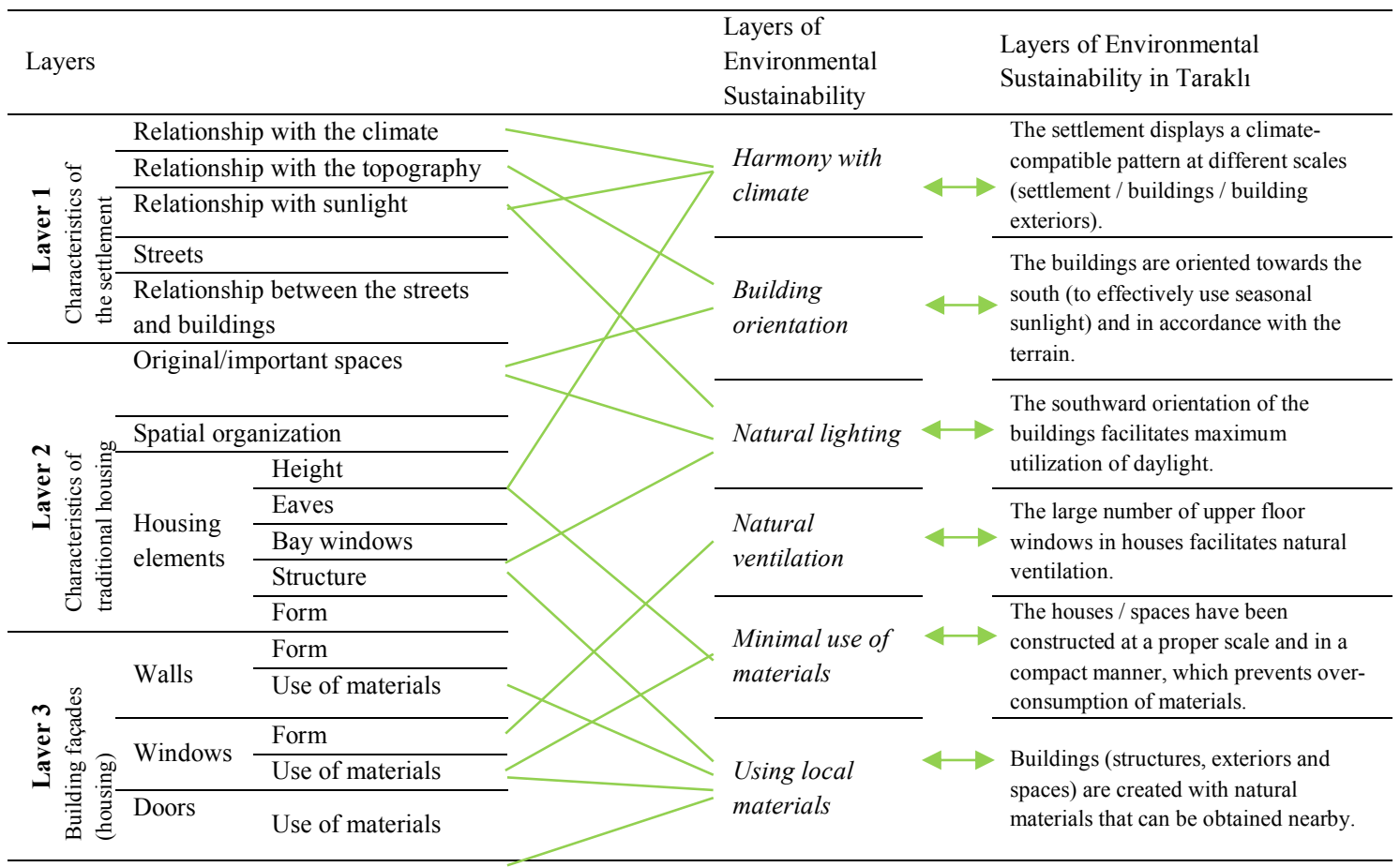




\section{Conclusion}

"Vernacular architecture does not go through fashion cycles. It is nearly immutable, indeed, unimprovable, since it serves its purpose to perfection.”

Bernard Rudofsky, 1964

The 21 st century is going to be a critical period for humanity. Increasingly, people are being confronted with the fact that they are rapidly consuming resources and destroying the world in the process. Of course, those resources are not unlimited. So how have we wound up in this quandary? Is there anything that can be done? How can a light be shone upon this dark path we find ourselves on? Of course, enlightenment will only be possible with a holistic approach. Movements that do not become a natural reflex, no matter how powerful they may be, will fail to protect life and the world at large. Taking a sincere a forward step now, for example by turning to the countryside, could be one rational approach. If we consider that we are living in critical times regarding our relationship with nature, the importance of local knowledge concerning architecture, which has always been closely linked to the natural world, becomes tacitly clear (Authors, 2014). In many ways, the sensitive approach we seek is already present in rural life. All around the world, indigenous people have come up with livable and sustainable solutions, but not by making great efforts or engaging in laborious research. What they do is a natural consequence of their own life practices. Knowledge about how to preserve nature, and all that lives in it, guarantees its existence, and in many places, people's futures are secured in the countryside. For them, the idea of loving nature is not something that needs to be taught, and it very well may not even existbecause it is a part of life itself. Protecting natural resources is the equivalent of protecting their houses and children. And individuals cannot do that alone for the simple reason that it is embedded in a social attitude.

The settlement of Taraklı illustrates all those features of rural-traditional architecture. This accumulation of knowledge, which developed hand-in-hand with nature, has led to forms of housing and a cultural lifestyle that have existed for centuries. In this approach, which has emerged as an extension of nature instead of a struggle against it, the basic criteria of sustainable architecture automatically comes into being. The effective usage of the topography and climate-compatible buildings, as well as sunlight, are instructive in terms of making minimal interventions into the environment, energy efficiency and conscientious consumption of resources. At the same time, the use of local, natural materials offers numerous advantages as regards the construction of 
healthy spaces that fulfill the needs of the people. Moreover, the buildings created through the use of these materials also spontaneously bring into being the characteristic identity of the place.

Today, we cannot reconstruct the settlements of the past, but we can maintain the order and environmental consistency of traditional settlements through patterned architectural language (Alexander, 1979). At this point, it should be emphasized that we need to try to understand and learn from what we are seeking rather than merely note the physical existence of rural settlements. Efforts to build up the present and future on such a basis will mark an important step forward in ensuring that our living environments are sustainable.

\section{References}

Aktürk S., Durak, S.\& Arslan, T.V. 2019. The concept of authenticity and commodification in sustainable tourism and examining of Cumalıkızk and Tarakl1. International Journal of Society Researches, 13(19), 2200- 2225.

Alexander, C. 1979. The timeless way of building, Oxford University Press, New York.

Aran, K. 2000. Barınaktan öte anadolu kır yapıları

(Beyond shelter: anatolian indigenous buildings), Tepe İnş.San A.Ş., İstanbul.

Authors. 2014.

Authors. 2019.

Başoğlu, S. 2017. Sakarya Taraklı bölgesinde mimari doku ve restorasyon süreçleri (Architectural tissue and restoration processes in Sakarya tarakli region) Haliç University, Institute of Science, Master Thesis, İstanbul

Benli, G. \& Kan T. 2013. Conservation problems of adobe architectural examples in 3 Sakarya Province Taraklı District and solution proposals, (Proceeding) kerpic'13 - New Generation Earthern Architecture: Learning from Heritage International Conference, Istanbul.

Davulcu, M. 2009. Sakarya Yöresi Kırsal Yerleşmelerinde Konut Mimarisi ve Ustalık Geleneği Üzerine Bir İnceleme (A Study on House Architecture and Master Tradition in the Rural Settlements of Sakarya Province), Kastamonu Eğitim Dergisi, May1s, 17(2), 687-706.

Degirmenci, I., \& Sarıbıyık, M. 2015. Tarihi mekanlarda sürdürülebilirlik bağlamında cittaslow hareketi: Taraklı örneği, (Cittaslow movement in the context of 
sustainability in historical places: exaple of Tarakl1) 2.Uluslararasi Sürdürülebilir Yapılar Sempozyumu, Gazi University, Ankara, 612-620.

Demir,E. 1988. Taraklı'da tarihi çevre değerlerini koruma amaçlı bir inceleme, (An investigation to protect historical environment values in Taraklı) ITU, Institute of Science, Master Thesis, İstanbul.

Eminağaoğlu, Z., \& Çevik, S. 2007. Design politics and tools for rural areas, Gazi Univ. Journal of Engineering and Architecture, 22(1), pp157-162.

Erek, H. 2015. Sakarya ili adapazarı ilçesi taraklı yerleşimi tarihi evlerinin ekolojik bağlamda tasarım ilkelerinin araştırılması (An investigation of design principles of the historical houses of Sakarya province Adapazarı county Taraklı settlement within ecological contex), Trakya University, Institute of Science, Master Thesis, Edirne.

Kan, H. 2009. Taraklı yerleşimindeki tarihi dokunun sürdürülebilirliği bağlamında kentsel koruma ve geliştirme stratejileri (Urban conservation and development strategies in the context of the sustainability of the historical fabric in Tarakl1 settlement) Bartın University, Institute of Science, Master Thesis, Bartın.

Koca, F. 2015. An ontological approach to the conservation conception of the authentic character and cultural heritage of traditional settlement patterns in Turkey, Planlama, 25(1), 32-43, 10.5505/planlama.2015.76486 .

Sabatino, M. 2010. Documenting Rural Architecture, by Giuseppe Pagano, Journal of Architectural Education, 63:2, 92-98. 10.1111/j.1531-314X.2010.01070.x

Oliver, P. 1998. Encyclopaedia of vernacular architecture of the world, Cambridge University Pres, Cambridge.

Özkan, S.S. 2008. Taraklı'nın fiziksel ve tarihsel dokusu, sivil ve anıtsal mimarlık örnekleri, Hacı Rıfatlar Konağı restorasyonu (Physical and historical properties of Taraklı, civil and monumental architecturel samples, restoration of Hacı Rifatlar Mansion) YTU, Institute of Science, Master Thesis, İstanbul

Özyer, H.B. 2008. Construction process and techniques of traditional houses in tarakl//sakarya: an introductory model for web-based gis applications, METU, Institute of Science, Master Thesis, Ankara

Rudofsky, B. 1964. Architecture without Architects, The Museum of Modern Art: Distributed by Doubleday, Garden City, N.Y

Seymen, F. 2008. Taraklı'da geleneksel sivil mimaride kullanılan yapım teknikleri ve Sadık Özen Evi restorasyon önerisi, (Construction technics applied to civil 
architecture in Taraklı and Sadik Özen House restoration proposal) YTU, Institute of Science, Master Thesis, İstanbul

Sözen, M. 2012. Anadolu'da Kırsal Mimarlık (Rural Architecture in Anatolia), ÇEKÜL Vakfi, İstanbul.

Şenol, P. \&, Akan, A. E. 2011. Rural life/rural housing: traditional rural housing production as a lifestyle -case of kizilcik village, SDU Faculty of Arts and Sciences Journal of Social Sciences, 24,143-60.

Turgay, T. \&, Erkuş Buyruk, P. 2017. Geleneksel Taraklı evleri ve yapılarda bozulma nedenleri. (Traditional Tarakl1 houses and urban conservation) Journal İleri $\begin{array}{llll}\text { Teknoloji Bilimleri } & \text { 6ergisi, }\end{array}$ https://dergipark.org.tr/tr/pub/duzceitbd/issue/32369/347100

Yücel, A. 2000. Hasan Fathy ve Sedad Hakkı: iki mizaç, iki mimari, (Hasan Fathy and Sedad Hakkı: two humour, two architecture) Hasan Fathy, Boyut Yayın Grubu, İstanbul.East Asian Studies, 6(2), 235-2 